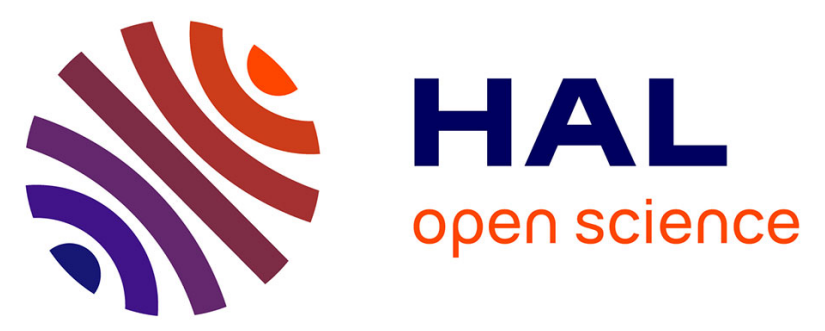

\title{
Identification of parasitoses in a child burial from Adak Island (Central Aleutian Islands, Alaska)
} Françoise Bouchet, Dixie West, Christine Lefevre, Debra Corbett

\section{To cite this version:}

Françoise Bouchet, Dixie West, Christine Lefevre, Debra Corbett. Identification of parasitoses in a child burial from Adak Island (Central Aleutian Islands, Alaska). Comptes rendus de l'Académie des sciences. Série III, Sciences de la vie, 2001, 324 (2), pp.123-127. 10.1016/S0764-4469(00)01287-7 . hal-02088273

\section{HAL Id: hal-02088273 https://hal.science/hal-02088273}

Submitted on 7 Oct 2019

HAL is a multi-disciplinary open access archive for the deposit and dissemination of scientific research documents, whether they are published or not. The documents may come from teaching and research institutions in France or abroad, or from public or private research centers.
L'archive ouverte pluridisciplinaire HAL, est destinée au dépôt et à la diffusion de documents scientifiques de niveau recherche, publiés ou non, émanant des établissements d'enseignement et de recherche français ou étrangers, des laboratoires publics ou privés. 


\title{
Identification of parasitoses in a child burial from Adak Island (Central Aleutian Islands, Alaska)
}

\author{
Françoise Bouchet $^{\mathrm{a} *}$, Dixie West ${ }^{\mathrm{b}}$, Christine Lefèvre ${ }^{\mathrm{c}}$, Debra Corbett ${ }^{\mathrm{d}}$ \\ a Laboratoire de paléoparasitologie, ESA 8045 (CNRS), université de Reims, 51, rue Cognacq-Jay, 51096 Reims \\ cedex, France \\ ${ }^{\mathrm{b}}$ Department of Anthropology, University of Kansas, Lawrence, KS 66045, USA \\ c Laboratoire d'anatomie comparée, ESA 8045 (CNRS), Muséum national d'histoire naturelle, 55, rue Buffon, \\ 75005 Paris, France \\ d US Fish and Wildlife Service, 1011 East Tudor Road, Anchorage, AL 99503, USA \\ Received 21 September 2000; accepted 23 October 2000
}

Communicated by Jean Rosa

\begin{abstract}
Bothriocephalid (Diphyllobothrium pacificum) and Ascarid (Ascaris lumbricoides) eggs have been identified in a sample taken in the abdominal cavity of a child skeleton found in Zeto Point (ADK-011), an archaeological site on Adak Island in the Central Aleutian Islands (Alaska). (C) 2001 Académie des sciences/Éditions scientifiques et médicales Elsevier SAS
\end{abstract}

paleoparasitology / Ascaris / Diphyllobothrium / Aleutian Islands / Helminths

Résumé - Identification de parasitoses dans une sépulture d'enfant de l'île d'Adak (archipel des Aléoutiennes, Alaska). Des œufs de bothriocéphale (Diphyllobothrium pacificum) et d'ascaris (Ascaris lumbricoides) ont été identifiés dans un prélèvement issu de la cavité abdominale d'un squelette d'enfant découvert dans le site archéologique de Zeto Point (ADK-011), dans les îles Aléoutiennes (Alaska). (C) 2001 Académie des sciences/Éditions scientifiques et médicales Elsevier SAS

paléoparasitologie / Ascaris / Diphyllobothrium / îles Aléoutiennes / Helminthes

\section{Version abrégée}

En 1999, le projet Archéologie et paléobiologie des îles Aléoutiennes occidentales a mis au jour une sépulture humaine dans les niveaux supérieurs d'un amas coquillier du site de Zeto Point, sur la côte nord-est de l'île d'Adak (archipel des Aléoutiennes, Alaska). Le squelette, en connexion et presque complet, est celui d'un enfant de 6 ou 7 ans -comme en témoigne l'éruption des premières molaires - qui a été enterré sur le côté gauche en position fotale. Les genoux étaient remontés sur la poitrine, les bras fléchis, les mains reposant sous le menton. Une datation du collagène de l'os d'une côte indique $840 \pm 40$ B.P.
Deux échantillons d'environ $150 \mathrm{~g}$ de matière organique ont été collectés en vue d'une analyse paléoparasitologique. Le bon état de conservation du squelette ainsi qu'une fouille soigneuse ont permis aux archéologues de localiser de façon précise l'emplacement de la cavité abdominale de l'enfant enterré, et le premier échantillon (\#735781) a été prélevé dans cette région $\mathrm{du}$ corps. Le second échantillon (\#735782) est un échantillon de contrôle, prélevé à proximité de la sépulture.

L'échantillon de contrôle a livré des résultats négatifs, alors que, dans l'échantillon prélevé dans la sépulture, des œufs d'Ascaris et de Diphyllobothrium ont été identifiés. Les oufs d'Ascaris, de 60 à $62 \mu \mathrm{m}$ de

* Correspondence and reprints.

E-mail address: francoise.bouchet@univ-reims.fr (F. Bouchet). 
diamètre, sont très bien conservés et présentent une coque mamelonnée très caractéristique. Les oufs de Diphyllobothrium mesurent en moyenne $57 \mu \mathrm{m} \times 39$ $\mu \mathrm{m}$. Leur coque est fine et sans protubérance sur la partie opposée à l'opercule, lequel est la plupart du temps absent.

Les analyses morphologiques et morphométriques des restes archéologiques d'œufs de parasites, l'association des deux genres de parasites dans un même individu et les données sur la faune de l'île d'Adak ont permis de préciser l'identification des deux genres de parasites.

Ascaris sp. est un des parasites les plus fréquemment identifiés dans les coprolithes humains et animaux archéologiques. Leurs œufs ont une coque très résistante, propriété liée à leur cycle biologique qui implique un passage dans le sol. Ils peuvent conserver leur pouvoir infestant in situ pendant de nombreuses années, mais les coques des œufs fossilisés peuvent perdurer encore plus longtemps. Les plus anciens œufs d'Ascaris sp. ont été trouvés dans la grotte pléistocène d'Arcy-sur-Cure (Yonne, France), dans des niveaux vieux de quelque 30000 ans. Sur le continent américain, des oufs d'Ascaris ont été mis au jour dans différents contextes préhistoriques.

Il n'existe que deux espèces d'Ascaris : l'un est un parasite de l'homme (A. lumbricoides), l'autre est un parasite du porc (A. suum). Dans le cas de la sépulture d'enfant d'Adak, nous pouvons sans équivoque éliminer A. suum, le porc étant absent des îles Aléoutiennes à l'époque de l'inhumation de cet enfant.

Six espèces de Diphyllobothrium ont été décrites en Alaska, dont cinq sont des parasites de l'homme. La mieux connue est D. latum, qui aurait été introduite dans le nouveau monde par les immigrants. Sa présence potentielle a été identifiée dans des coprolithes d'Indiens préhistoriques du Pérou, dans le Michigan et dans le sud-ouest des États-Unis. L'espèce la plus commune sur la côte pacifique est $D$. pacificum. Elle effectue une partie de son cycle biologique en utilisant des hôtes tels que les lions de mer, les phoques et différentes espèces de poissons d'eau douce et d'eau de mer avant de se développer dans la cavité abdominale de l'homme. Cette espèce a été identifiée dans des coprolithes du Pérou et du Chili. Une étude parasitologique sur une momies de l'île Kagamil (Aléoutiennes orientales) a fourni des résultats négatifs. À Buldir (Aléoutiennes occidentales), les auteurs ont identifié Diphyllobothrium dans un échantillon de matière organique prélevé dans une aire d'occupation anthropique (et non sur un individu humain), sans qu'il soit possible de conclure à une cestodose anthropique. À Zeto Point, la taille des oufs archéologiques, $57 \times 39 \mu \mathrm{m}$ en moyenne, permet de les attribuer à l'espèce $D$. pacificum plutôt que D. latum, dont les œufs ont un diamètre de $70 \mu \mathrm{m}$. L'absence de protubérance au pôle opposé à l'opercule, propre à l'espèce pacificum et observée sur tous les oufs de Zeto Point, confirme cette détermination, de même que les données archéozoologiques, qui mettent en évidence le rôle important joué par les lions de mer et les poissons dans l'alimentation des anciens Aléoutes.

Les données parasitologiques actuelles indiquent que l'infestation par le Diphyllobothrium est largement répandue de nos jours dans les régions circumpolaires et parmi les populations vivant à proximité des Grands Lacs de l'Amérique du Nord. Ce parasite a également été identifié dans une population Eskimo de l'ouest de l'Alaska, avec une prévalence variant de 15 à $30 \%$ selon la saison.

La présence de ces parasites chez ce jeune individu a certainement entraîné un affaiblissement général de l'enfant. Il n'est pas possible ici d'évaluer la charge parasitologique présente dans l'intestin de cet enfant, et il est donc difficile de conclure que ces parasites sont directement responsables de son décès. Cependant, il est fort probable que les parasites intestinaux ont affaibli ce jeune individu.

Cette analyse est la première qui met en évidence un parasitisme dans un squelette humain des îles Aléoutiennes. Elle fournit des informations sur le mode de vie des anciens chasseurs aléoutes à l'époque préhistorique. La pratique aléoute d'une sédentarité saisonnière a entraîné la formation d'amas de déchets contenant des matières fécales dans des sols humides et froids, mais non gelés, dans lesquels les œufs d'Ascaris pouvaient survivre. En dépit d'une bonne organisation des zones de rejet, la transmission par voie orale est toujours envisageable. Des habitudes d'hygiène inadéquates, combinées avec un taux de survie des oufs d'Ascaris dans les zones de rejet proches des zones d'habitations auraient pu entraîner des taux d'infection élevés. Les déplacements saisonniers ainsi que la taille limitée des groupes humains ont cependant probablement aidé à réguler la diffusion des parasites parmi les Aléoutes.

Cette étude ne concernant qu'un seul squelette, nous ne pouvons ici que présenter des résultats qui devront être corroborés à l'occasion d'analyses d'autres sépultures aléoutes. 


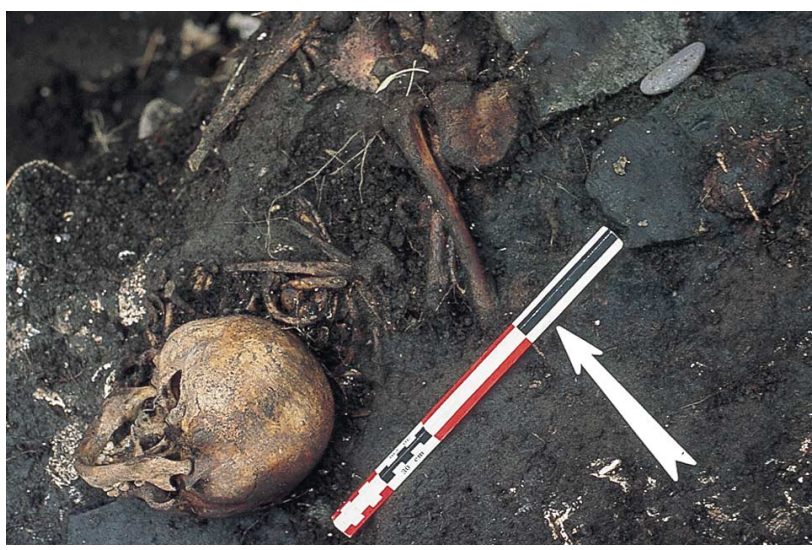

Figure 1. Child skeleton excavated at Zeto Point (site ADK-011).

\section{Introduction}

In 1999, the Western Aleutian Archaeological and Paleobiological Project excavated a site containing approximately 75 house pit depressions at Zeto Point (ADK-011), in the vicinity of Clam Lagoon on the northeast side of Adak Island [1]. The excavated feature was an abandoned house depression, re-used as a dump for human debris, with numerous cockles (Clinocardium sp.), and bones of marine mammals, birds and fishes. Radiocarbon dates suggest the feature was used between $2490 \pm 50$ B.P. (Beta-132879) (bottom level of unit 2) and $440 \pm 40$ B.P. (level 3 of unit 1) (Beta-132878). A human burial was uncovered slightly atop and within the cockle midden (figure 1). Morphological and morphometrical analyses were completed by West. The skeleton is of a very nearly complete and articulated child, buried on its left side in the fetal position. The knees were drawn up close to the chest and arms were bent with hands lying just under the chin. As indicated by eruption of the first molars, the child was 6-7 years old when he/she died. A standard AMS date using bone collagen extraction from ribs indicated a death circa $840 \pm 40$ B.P. (Beta-133745).

\section{Materials and methods}

Two samples of approximately $150 \mathrm{~g}$ of organic material were collected and analyzed. Good preservation of the skeleton and careful excavation techniques allowed archaeologists to precisely locate the abdominal cavity of the buried child and the first sample (\#735781) comes from this area of the body. The second sample (\#735782) is a control sample, collected outside of, but close to, the burial.

Samples were rehydrated for 7 days in a solution of $0.5 \%$ trisodium phosphate $[2,3]$. After being ground in a mortar, the suspension was treated with ultrasound (ultrasonic Sonorex 103K) at $60{ }^{\circ} \mathrm{C}$ for $1 \mathrm{~min}$, then sieved through 315- $\mu \mathrm{m}, 160-\mu \mathrm{m}, 50-\mu \mathrm{m}$ and $25-\mu \mathrm{m}$ meshes. The

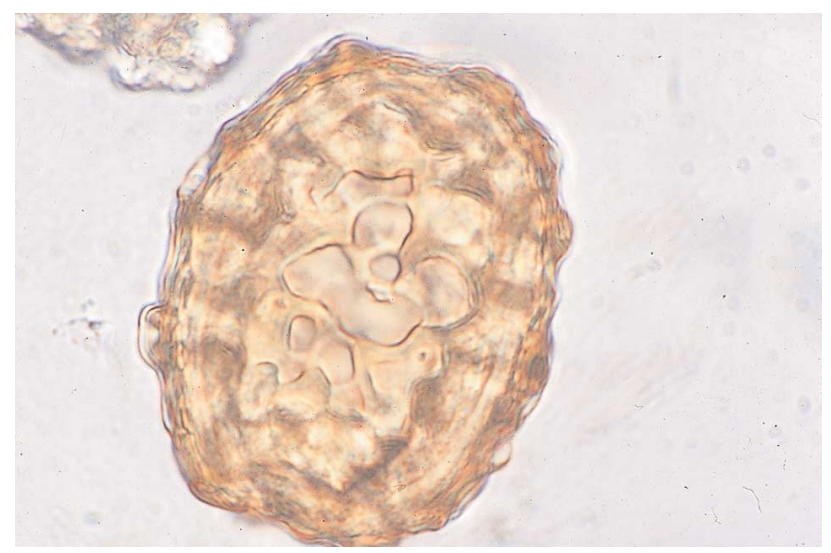

Figure 2. Egg of Ascaris lumbricoides from ADK-011 (diameter: 60 $\mu \mathrm{m})$.

last two siftings were kept and treated with two complementary enrichment techniques: 1) simple sedimentation technique: the reading of the bottom by optical microscopy is carried out with slides after centrifugation (2 500 $\mathrm{tr} / \mathrm{min}$ for $3 \mathrm{~min})$; and 2) flotation techniques which must be adapted to the preservation of the eggs of the various parasite species. Due to the different reactions to taphonomic processes, the permeability of the egg shell varies when submitted to different chemical reactives. This diversity requires the use of various solutions (Willis, Teuscher, de Thoulet, saturated saccharose) with densities from 1.05 to $1.4[4,5]$.

\section{Results}

The control sample (\#735782) taken in the sediment adjacent to the skeleton of the child was negative. Ascaris sp. and Diphyllobothrium sp. were identified in sample \# 735781, associated with the human gut contents. Eggs of Ascaris sp. are 60-62 $\mu \mathrm{m}$ in diameter and present a very well preserved and characteristic mamillated shell (figure 2). Diphyllobothrium eggs measure $57 \mu \mathrm{m} \times 39 \mu \mathrm{m}$ on average (figure 3). They possess a thin shell with no bump on the side from opposite the operculum. Most of the time this opperculum is lacking.

\section{Discussion}

Morphologic and morphometric analyses of the archaeological remains of parasite eggs, the association of two genera of parasites in a single individual, and the available data on the fauna of Adak Island, allow for precise identification of the two parasites.

\subsection{Ascaris: giant roundworm}

Ascaris sp., along with Trichuris sp., is the parasite most commonly recovered in ancient human and animal coprolites [5]. There are only two species of Ascaris; one is a 


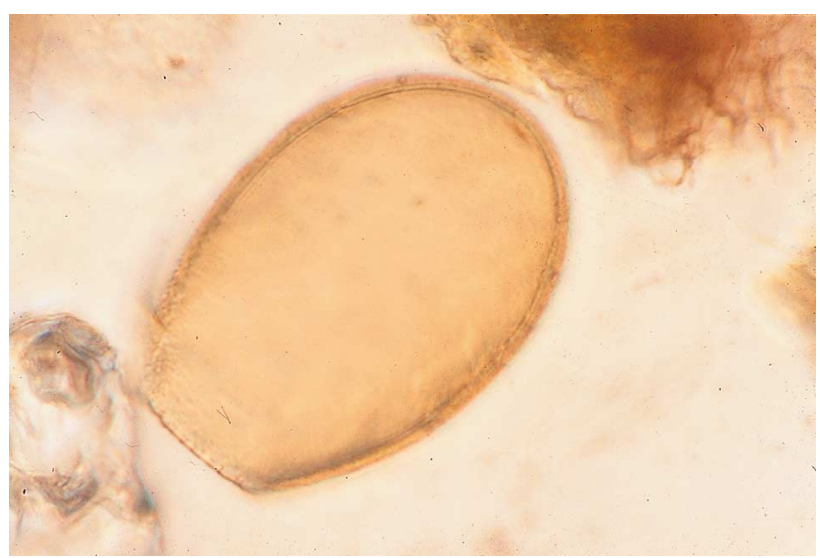

Figure 3. Egg of Diphyllobothrium pacificum from ADK-011 $(57 \mu \mathrm{m}$ $\times 39 \mu \mathrm{m})$.

parasite of man (A. lumbricoides), the other of the pig (A. suum). These eggs are extremely tough shelled, due to their biological cycle which requires a transit phase in the ground. They can maintain their infestation power in situ for 7 years [7]. The egg shell lasts even longer. The most ancient fossilized eggs of Ascaris sp. have been recovered in France, in the Pleistocene cave of Arcy-sur-Cure, Yonne, 30000 years old [8]. In the New World, Ascaris eggs have been recovered in various prehistoric contexts [3, 6, 9-19].

In the case of the Aleut child burial, we can unequivocally eliminate $A$. suum; hogs did not live in the Aleutian Islands at the time the child died and was buried.

\subsection{Diphyllobothrium: tapeworm}

In Alaska, six species of Diphyllobothrium have been described, five of them are parasites of man [20-22]. The best known is $D$. latum, which was supposedly introduced in the New World by the immigrants [23]. Its potential presence has been identified in coprolites from Prehistoric Indians in Peru [3], in Michigan [24] and in the southwestern United States sites [16]. It is listed in the review by Klicks [17].

The most common species on the Pacific coast is D. pacificum, for which sea lions, seals and a variety of freshwater and marine water fishes are the intermediary hosts before developing in the abdominal cavity of humans [25], but the identification of intermediate hosts and the variety of final hosts are still tentative [26]. Nevertheless, the species has been identified in coprolites from Peru [12], Chile [27], and was mentioned in the review by Horne [6].

In the eastern Aleutian Islands, a parasitological analysis conducted by Zimmerman [28, 29] on a mummy from Kagamil Island provided negative results. On Buldir Island, in the western Aleutians, Bouchet et al. [5] identified tapeworm eggs in a sample of organic sediment associated with a living area, rather than a human individual, but it was impossible to conclude that this was an anthropic cestodosis. In the case of Zeto Point, the morphometry and morphology of the recovered eggs make possible the specific identification of $D$. pacificum. Indeed, the size of the eggs, $57 \mu \mathrm{m} \times 39 \mu \mathrm{m}$ on average, is clearly smaller than the eggs of $D$. latum which are $70 \mu \mathrm{m}$ in diameter $[27,30]$. The absence of a protuberance on the opposite side from the operculum is also a peculiar characteristic of $D$. pacificum. This result is supported by the zooarchaeological data (work in progress by Lefèvre) which demonstrate the important role played by sea lions and fish in the diet of ancient Aleuts. Humans probably became infected by eating raw or undercooked fish, and fish remains are numerous in the Zeto Point site where the child was exhumed.

Present parasitological data indicate that tapeworm infestation is "widespread today in circumpolar regions" [6], and occurs in populations living in the vicinity of the Great Lakes of North America [31] This parasite was also identified in an Eskimo population of western Alaska with a prevalence varying from 15 to $30 \%$, depending on the season [20].

\section{Conclusion}

The presence of such a parasite infestation in this young individual must have certainly caused a general weakening of the child. Although ascaridiosis is an illness of the digestive tract without serious consequences for the health of the bearer, bothriocephalosis is potentially much more debilitating. Since it is not possible here to evaluate the parasite load in the intestine of the child, it is difficult to conclude that these parasites were directly responsible for its death. Nevertheless, it is likely that intestinal parasites debilitated the general hardiness of such a young individual.

This report provides the first documented evidence of prehistoric parasitism in a human skeleton from the Aleutians. It also provides new information about the prehistoric life ways of Aleut hunter gatherers. Although many parasite infestations are associated with the advent of agriculture [32], parasitism also occurs in relatively mobile hunter gatherers. The Aleut practice of seasonal sedentism resulted in the build-up of trash middens containing human fecal materials in a moist, cool - but rarely freezing - soil environment which would have favored Ascaris egg survival. Although the disposal of human waste was well organized, parasite eggs could have easily found their way into the mouths of young Aleut children as well as older individuals. Inadequate hygiene practices, combined with high survival rates of Ascaris eggs in refuse areas adjacent to living quarters would have promoted high infection rates. However, seasonal movements, limited band size, and overall small population size may have curtailed spread of the parasites among the Aleuts.

Since this study concerns only one skeleton, the ideas presented here about past Aleut life ways should be taken as hypotheses to be tested as future Aleut burials are analyzed. 
Acknowledgements. The 1999 field season has been supported by the National Science Foundation (grant OPP-9614472), the U.S. Fish and Wildlife Service and

\section{References}

[1] West D., Corbett D.G., Lefèvre C., The Western Aleutians Archaeological and Paleobiological Project: Annual report for 1999, Report on file, National Science Foundation, Washington D.C., 1999.

[2] Van Cleave H.J., Ross J.A., A method for reclaiming dried zoological specimens, Science 105 (1947) 318.

[3] Callen E.O., Cameron T.N., A prehistoric diet as revealed in coprolites, New Scientist 8 (1960) 35-39.

[4] Bouchet F., Bentrad S., Recovery of equine helminth eggs in a medieval lacustrine settlement, Vet. Rec. 6 (1997) 601-602.

[5] Bouchet F., Lefèvre C., West D., Corbett D.G., First paleoparasitological analysis of a midden in the Aleutian Islands (Alaska): results and limits, J. Parasitol. 85 (1999) 369-372.

[6] Horne P., A review of evidence of human endoparasitism in the pre-Columbian New World through the study of coprolites, J. Archaeol. Sci. 12 (1985) 299-310.

[7] Storey G.W., Philipps R.A., The survival of parasite eggs throughout the soil profile, Parasitology 91 (1985) 585-590.

[8] Bouchet F., Baffier D., Girard M., Morel P., Paicheler J.C., David F., Paléoparasitologie en contexte pleistocène : premières observations à la Grande Grotte d'Arcy-sur-Cure (Yonne), France, C. R. Acad. Sci. Paris Sér. III 319 (1996) 147-151.

[9] Fry G.F., Ovum and parasite examination of Salts Cave human paleofeces, in: Watson P.J. (Ed.), Archaeology of the Mammouth Cave Area, Academic Press, New York, 1974, p. 61.

[10] Fry G.F., Analysis of prehistoric coprolites from Utah, Anthropol. Pap. Univ. Utah 97 (1977) page?.

[11] Hall H.J., Untitled note, Paleopathol. Newslett 21 (1978) 6.

[12] Patrucco R., Tello R., Bonavia D., Parasitological studies of coprolites from pre-Hispanic Peruvian populations, Curr. Anthropol. 24 (1983) 393-394.

[13] Reinhard K.J., Hevly R.H., Anderson G.A., Helminths remains from prehistoric Indian coprolites on the Colorado Plateau, J. Parasitol. 73 (1987) 630-639.

[14] Faulkner C.T., Patton S., Strawbridge Johnston S., Prehistoric parasitism in Tennessee. Evidence from the analysis of desiccated fecal material collected from Big Bone Cave, Van Buren County, Tennessee, J. Parasitol. 75 (1989) 461-463.

[15] Confalioneri U.E., Araujo A.J., Ferreira L.F., Enteroparasitos em indios Yanomami, Mem. Inst. Oswaldo Cruz 84 (suppl. IV) (1989) 111113. the Institut français pour la recherche et la technologie polaires (Program 301).
[16] Reinhard K.J., Archeoparasitology in North America, Am. J. Phys. Anthropol. 82 (1990) 145-163.

[17] Klicks M.M., Helminths as heirlooms and souvenirs: a review of New World paleoparasitology, Parasitol. Today 4 (1990) 93-99.

[18] Riley T.J., Ascarids, American Indians and modern world, Perspect. Biol. Med. 36 (1993) 369-375.

[19] Horne P.D., Tuck J.A., Archeoparasitology at a 17th century colonial site in Newfoundland, J. Parasitol. 82 (1996) 512-515.

[20] Rausch R.L., Scott E.M., Rausch V.R., Helminths in Eskimos in Western Alaska with particular reference to Diphyllobothrium infection and anemia, Trans. R. Soc. Trop. Med. Hyg. 61 (1967) 351-357.

[21] Rausch R.L., Hilliard D.K., Studies on the helminth fauna of Alaska, Can. J. Zool. 48 (1970) 519-549.

[22] Acha N.P., Szyfres B., Zoonoses et maladies transmissibles communes à l'homme et aux animaux, Office international des épizooties, Paris, 1989, pp. 785-790.

[23] Von Bonsdorff B., Diphyllobothriasis in Man, Academic Press, London, 1977.

[24] McClary A., Notes on some late Middle Woodland coprolites, in: Fitting J.E. (Ed.), The Schultz Site at Green Point: a Stratified Occupation Area in the Saginaw Valley of Michigan, Memoir 4, University of Michigan Museum of Anthropology, 1972, pp. 131-136.

[25] Baer J.G., Diphyllobothrium pacificum, a tapeworm from sea lions endemic in man along the coastal area of Peru, J. Fish. Res. Board Can. 26 (1969) 717-723.

[26] Adams A.M., Murell K.D., Cross J.H., Parasites of fish and risk to public health, Rev. Sci. Tech. Off. Int. Epiz. 16 (1997) 652-660.

[27] Ferreira L.F., Araujo A.J., Confalonieri U.E., Nunez L., The finding of eggs of Diphyllobothrium in human coprolites (4100-1950 BC) from northern Chile, Mem. Inst. Oswaldo Cruz 79 (1984) 175-180.

[28] Zimmerman M.R., Aleutian and Alaskan mummies, in: Cockburn A., Cockburn E. (Eds.), Mummies, Disease and Ancient Cultures, Cambridge University Press, Cambridge, 1980, pp. 119-134.

[29] Zimmerman M.R., The paleopathology of an Aleutian mummy, Arch. Pathol. Lab. Med. 105 (1981) 638-641.

[30] Baer J.G., Miranda H., Fernandez W., Medina J., Human diphyllobothriasis, Z.f. Parasitenkunde 28 (1967) 277-289.

[31] Katz M., Despommier D., Gwadz R.W., Parasitic Diseases, Springer-Verlag, New York, 1982.

[32] Reinhard K.J., Cultural ecology of prehistoric parasitism on the Colorado Plateau as evidenced by coprology, Am. J. Phys. Anthropol. 77 (1988) 355-366. 